Матеріали науково-практично конференці з участю міжнародних спеціалістів «Актуальні питання діагностики, лікування, раціонально фармакотерапі, диспансеризаці та реабілітаці в практиці сімейного лікаря»

УДК 615.217.3:615.32:616.8-009.81:616.831-021.5-092.9

\title{
ВИВЧЕННЯ ВПЛИВУ $\alpha$-ЛІПОЄВО КИСЛОТИ НА ПОВЕДІНКОВІ РЕАКЦІ У ЩУРІВ З ЕКСПЕРИМЕНТАЛЬНИМ ЕКВІВАЛЕНТОМ РОЗСІЯНОГО СКЛЕРОЗУ
}

\author{
СО. О. Нефьодов, О. В. Кулик
}

Державний заклад “Дніпропетровська медична академія МОЗ України»

Однією з актуальних патологій нейродегенеративного характеру $є$ розсіяний склероз (PC) хронічне аутоімунне захворювання, при якому уражається мієлінова оболонка нервових волокон головного і спинного мозку. Захворювання виникає в молодому і середньому віці (15-40 років). Особливістю хвороби є одночасне ураження кількох різних відділів нервово системи, що призводить до появи у хворих різноманітних неврологічних симптомів.

Метою дослідження було проведення фармакологічного аналізу впливу $\alpha$-ліпоєво кислоти (50 мг/кг) на показники безумовно-рефлекторно активності тварин в тесті «відкрите поле» за умов експериментального алергічного енцефаломієліту (EAE) на тлі базово терапі солу-медролом.

Експериментальні дослідження виконані на 24 білих нелінійних щурах масою 200-220 г, які були поділені на 4 групи: I - інтактні тварини (пасивний контроль), n=6; II - щури з EAE (активний контроль), n=6; III - EAE + солу-медрол (СМ: 3,4 мг/кг), $\mathrm{n}=6 ; \mathrm{IV}-\mathrm{EAE}+\mathrm{CM}+\alpha$-ліпоєва кислота (50 мг/кг). EAE індукували одноразовою підшкірною інокуляцією енцефалітогенно суміші (ЕГС) в повному ад'юванті Фрейнда (ПАФ) з розрахунку 100 мг гомогенату гомологічного спинного мозку; 0,2 мл ПАФ (вміст убитих мікобактерій 5 мг/мл) і 0,2 мл фізіологічного розчину на тварину. ЕГС вводили в основу хвоста під легким ефірним наркозом в об'ємі 0,4 мл. Тестування рухово-дослідницько активності та емоційного стану експериментальних тварин проводили в останню добу введення препаратів в усіх дослідних групах: визначали кількість перетнутих квадратів (горизонтальна активність), вертикальних підйомів та заглядань у нірки (дослідницька активність), а також тривалість актів грумінгу та кіль- кість болюсів дефекаці (емоційний стан) протягом 3 хвилин.

Результатами досліджень безумовно-рефлекторно поведінки гризунів у тесті «відкрите поле» встановлено, що у тварин з експериментальним алергічним енцефаломієлітом реєструвалося суттєве зниження показників орієнтовно-дослідницько активності. Зокрема, показник горизонтально рухово активності у щурів з вказаною патологією був на $55 \%(p<0,05)$ нижчим, порівняно з групою пасивного контролю; при цьому також спостерігалося статистично значиме зменшення кількості проявів «ніркового» рефлексу в 2,3 раза $(p<0,05)$. Крім того, характерним було і виражене пригнічення вертикально рухово активності, яке проявлялося зниженням числа вертикальних підйомів на $56 \%(p<0,05)$, порівняно з групою інтактних тварин. Зазначені зміни свідчили про розвиток психоневрологічного дефіциту у гризунів з експериментальним алергічним енцефаломієлітом.

Поєднане застосування антиоксиданту берлітіону (50 мг/кг $\alpha$-ліпоєво кислоти) і метилпреднізолону сприяло посиленню горизонтально рухово активності дослідних тварин у 1,56 раза $(\mathrm{p}<0,05)$. Крім того, спостерігалося зростання на $100 \%$ $(\mathrm{p}<0,05)$ кількості підйомів на задні лапи та статистично достовірне збільшення на 73,9\% $(p<0,05)$ числа проявів «ніркового» рефлексу.

Таким чином, експериментальний аутоімунний енцефаломієліт ослабляє переважно рухову та дослідницьку активність щурів, не викликаючи суттєвих змін емоційного статусу; застосування $\alpha$-ліпоєво кислоти на тлі базово гормонально терапі модельовано патологі викликає відновлення всіх показників рухово та орієнтовно-дослідницько діяльності гризунів за умов ЕAE. 